Article

\title{
Unique Polyhalogenated Peptides from the Marine Sponge Ircinia sp.
}

\author{
Rogelio Fernández ${ }^{1}$, Asep Bayu ${ }^{2}$, Tri Aryono Hadi ${ }^{3}$, Santiago Bueno ${ }^{1}$, Marta Pérez ${ }^{1, * \mathbb{C} \text {, }}$ \\ Carmen Cuevas ${ }^{1}$ and Masteria Yunovilsa Putra ${ }^{2}$ (D)
}

1 Natural Products Department, PharmaMar S.A., Pol. Ind. La Mina Norte, Avda. de los Reyes 1, 28770 Colmenar Viejo (Madrid), Spain; rfernandez@pharmamar.com (R.F.); sbueno@pharmamar.com (S.B.); ccuevas@pharmamar.com (C.C.)

2 Research Center for Biotechnology, Indonesian Institute of Sciences, Jl. Raya Jakarta-Bogor No. Km46, Cibinong, Bogor, Jawa Barat 16911, Indonesia; asepbayu86@gmail.com (A.B.);

masteria.yunovilsa@gmail.com (M.Y.P.)

3 Research Center for Oceanography, Indonesian Institute of Sciences, Jl. Pasir Putih I, Ancol Timur, Jakarta 14430, Indonesia; tri.aryono.hadi@lipi.go.id

* Correspondence: mperez@pharmamar.com; Tel.: +34-91-823-4527

Received: 7 July 2020; Accepted: 27 July 2020; Published: 28 July 2020

\begin{abstract}
Two new bromopyrrole peptides, haloirciniamide A (1) and seribunamide A (2), have been isolated from an Indonesian marine sponge of the genus Ircinia collected in the Thousand Islands (Indonesia). The planar structure of both compounds was assigned on the basis of extensive 1D and 2D NMR spectroscopy and mass spectrometry. The absolute configuration of the amino acid residues in $\mathbf{1}$ and $\mathbf{2}$ was determined by the application of Marfey's method. Compound $\mathbf{1}$ is the first dibromopyrrole cyclopeptide having a chlorohistidine ring, while compound $\mathbf{2}$ is a rare peptide possessing a tribromopyrrole ring. Both compounds failed to show significant cytotoxicity against four human tumor cell lines, and neither compound was able to inhibit the enzyme topoisomerase I or impair the interaction between programmed cell death protein PD1 and its ligand, PDL1.
\end{abstract}

Keywords: marine sponge; Ircinia sp.; polyhalogenated peptides; Marfey's analysis

\section{Introduction}

Indonesia is located at the center of a biodiversity hotspot, and around 750 structures from Indonesian waters have been published in the last 50 years [1]. The structural diversity and bioactive properties of the compounds isolated from this region encouraged us to continue to investigate this area, which still remains largely unexplored. Thus, one of the recent PharmaMar expeditions was carried out in the Thousand Islands, in collaboration with Indonesian Institute of Sciences (LIPI). The Thousand Islands archipelago is located about 25 miles from the coast to the northeast of Jakarta; the collection site is an area full of gentle rock and coral slopes, and it is potentially a highly productive area, both in terms of the quantity and the nature of the biodiversity. In this paper, we describe the isolation of two new peptides isolated from an Ircinia specimen from this area.

Of all the marine organisms investigated, sponges (Porifera) are the most primitive multicellular animals with ample time to evolve into more complex living organisms. In fact, marine sponges are recognized as the richest sources of $\mathrm{MNP}$, contributing to nearly $30 \%$ of all marine natural products discovered so far [2]. Previous reports revealed that Marine sponges of the genus Ircinia are known as a rich source of varied bioactive natural products, including fatty acids [3], steroids [4,5], terpenes [6,7], macrolides [8,9], and peptides [10], many of which have biological activities. This structural diversity could be due to the fact that sponges harbor diverse microorganisms and in numerous cases, bacteria 
isolated from sponges or symbiotic bacteria are the true producers of the compounds found in their extracts [11]. Specifically, an intriguing group of Ircinia-derived peptides are assumed to be of microbial origin due to the presence of both D-amino acids and unusual amino acids, as illustrated by the cyclic hexapeptide waiakeamide from Ircinia dendroides [12] and the cyclotheonamides E4 and E5, which are cyclic pentapeptides also from Ircinia species [13].

Undeniably, among the compounds isolated from marine sources, linear and cyclic peptides are recognized as an important class with great structural diversity and a wide range of bioactivities, and these include the antimalarial carmabin A [14], the antiproliferative jaspamides [15], and the cytotoxic patellamides [16]. Furthermore, two marine peptide-derived products have reached the market: ziconotide [17] for analgesic use and a synthetic derivative of dolastatin 10 [18] linked to an antibody for the treatment of Hodgkin's lymphoma. PharmaMar has also developed a marine natural peptide Aplidin, which was originally found in the Ascidian Aplidium albicans and has recently been approved for commercialization in Australia for the treatment of multiple myeloma. Recent studies suggest that Aplidin may also have antiviral properties, and a clinical trial to treat patients with COVID-19 has been initiated.

In the course of our screening program to isolate novel compounds with antitumor properties from marine sources, the organic extract of an Ircinia specimen collected off the coast of the Thousand Islands showed hints of activity, and although the fractions did not confirm cytotoxicity, the chromatographic profiles along with the mass spectra showed peaks that were interesting enough for us to purify them. Thus, we have isolated two unique peptides haloirciniamide A (1) and seribunamide A (2). It is worth mentioning that the number of known peptides with a halogenated pyrrole ring is limited, with only cyclocinamides and corticiamide A [19] as well as gunungamide A [20] having been described as possessing chlorinated pyrrole rings. Although there are dozens of dibromopyrrolecarboxamide derivatives from porifera such as nagelamide [21] and carteramine [22], mainly from Agela and Stylissa species, compound $\mathbf{1}$ is the first example of a peptide containing a halogenated pyrrole ring in its structure. Indeed, haloirciniamide A represents a structurally unique cyclopeptide, since it also has an unprecedented chlorohistidine moiety. Furthermore, there are only two examples of tribromopyrrole rings derived from natural sources: 2,3,4-tribromopyrrole itself, which was isolated from the marine Poychaete Polyphysia crassa [23], and tribromopyrrol-2-methylphenol isolated from a coralline algal-associated Pseudoalteromone [24], with compound 2 being the first of its class.

Details of the isolation and structural elucidation of the new halogenated peptides $\mathbf{1}$ and $\mathbf{2}$ are provided. The results of cytotoxicity and other related antitumor programmed cell death protein (PD1) and TOPO-I screenings are also described.

\section{Results and Discussion}

\section{Isolation and Structure Elucidation}

The sponge Ircinia sp. was collected by hand while diving in the Thousand Islands (Indonesia). The specimen was repeatedly extracted using $\mathrm{CH}_{2} \mathrm{Cl}_{2}: \mathrm{MeOH}(1: 1 \mathrm{v} / \mathrm{v})$. The combined concentrated extracts, after vacuum liquid chromatography (VLC) and semipreparative reverse-phase HPLC separations, led to the isolation of the two pure compounds shown in Figure 1.

Compound 1 was isolated as an amorphous white solid. The isotopic distribution observed in the (+)-LRESIMS mass spectrum with four protonated ion $[\mathrm{M}+\mathrm{Na}]^{+}$peaks at $\mathrm{m} / \mathrm{z} 830,832,834$, and 836 in the ratio 3:6:3:1 respectively, showed the presence of two bromine atoms and a chlorine atom in the molecule. The presence of these halogens in the structure was confirmed by (+)-HRESI-TOFMS analysis, with the ion peak observed at $\mathrm{m} / \mathrm{z} 830.0400[\mathrm{M}+\mathrm{Na}]^{+}$corresponding to the molecular formula $\mathrm{C}_{25} \mathrm{H}_{32}{ }^{79} \mathrm{Br}_{2}{ }^{35} \mathrm{ClN}_{11} \mathrm{O}_{8} \mathrm{Na}$ (calcd. 830.0383). Interpretation of the mono NMR data $\left({ }^{1} \mathrm{H},{ }^{13} \mathrm{C}\right.$ and 1D-TOCSY) compiled in Table 1 and two-dimensional NMR spectra (gHSQC, gCOSY, gHMBC, and 2D-TOCSY) in $\mathrm{CD}_{3} \mathrm{OD}$ led to identification of 6 spin systems. Taking into consideration the seven carbonyl carbon resonances $\left(\delta_{C} 161.4-175.8\right)$ and the number of $\alpha$-amino acid proton signals 
$\left(\delta_{\mathrm{H}} 4.06-4.84\right)$, the peptide nature of compound 1 was expected. This hypothesis was confirmed by the $\mathrm{NH}$ signals observed in the ${ }^{1} \mathrm{H}$ NMR spectrum in $\mathrm{CD}_{3} \mathrm{OH}\left(\delta_{\mathrm{H}} 7.13-12.68\right)$ and DMSO- $\mathrm{d}_{6}\left(\delta_{\mathrm{H}} 7.37-12.03\right)$, with the latter solvent being chosen for full structural elucidation. The COSY correlations observed between methines at $\delta_{\mathrm{H}} 4.23 / \delta_{\mathrm{C}} 50.5$ and $\delta_{\mathrm{H}} 4.49 / \delta_{\mathrm{C}} 51.5$ with the diastereotopic methylenes at $\delta_{\mathrm{H}} 2.87$, $3.13 / \delta_{\mathrm{C}} 49.2$ and $\delta_{\mathrm{H}} 3.22,4.04 / \delta_{\mathrm{C}} 40.5$ respectively, indicated the presence of two 2,3-diaminopropionic acid units (Figure 2). Both amino acids were directly connected based on the HMBC correlation of the NH signals at $\delta_{\mathrm{H}} 9.11$ for Dap1 and $\delta_{\mathrm{H}} 7.72$ for Dap2 with the same carbonyl carbon at $\delta_{\mathrm{C}} 169.5$. The next amino acid present in the peptide core was an isoserine with a methylene group at $\delta_{\mathrm{H}} 2.75$, $3.47 / \delta_{\mathrm{C}} 42.8$, a methine carbon at $\delta_{\mathrm{H}} 4.13 / \delta_{\mathrm{C}} 67.8$, and an $\mathrm{NH}$ signal at $\delta \mathrm{H} 8.23$. Isoserine was linked to the Dap2 by the correlation between $\mathrm{NH}$ at $\delta_{\mathrm{H}} 8.23$ and the carbonyl carbon of Dap2 at $\delta_{\mathrm{C}} 170.6$. In addition, an $\mathrm{HMBC}$ correlation of the methine carbon at $\delta_{\mathrm{H}} 4.13$ and the $\mathrm{NH}$ signal at $\delta_{\mathrm{H}} 7.13$, which belongs to a unit of isoasparagine $\left(\delta_{\mathrm{H}} 4.58 / \delta_{\mathrm{C}} 48.4, \delta_{\mathrm{H}} 2.80,3.09 / \delta_{\mathrm{C}} 35.0\right)$, with the carbonyl group at $\delta_{\mathrm{C}} 170.6$ allowed the sequence of amino acids to be continued. Finally, the peptide ring was closed by an NMe-histidine $\left(\delta_{\mathrm{H}} 3.99 / \delta_{\mathrm{C}} 65.6, \delta_{\mathrm{H}} 3.05 / \delta_{\mathrm{C}} 25.0\right)$, whose $\mathrm{N}$-methyl group showed an HMBC correlation with carbons belonging to the carbonyl group of iAsn at $\delta_{C} 173.5$ and its own methine at $\delta_{C}$ 65.6, with an additional HMBC correlation between the $\alpha$-aminoacid proton signal of NMe-histidine and the NH signal at $\delta_{\mathrm{H}} 9.11$ of Dap1 with the carbonyl carbon at $\delta_{\mathrm{C}} 169.0$ (Figure 2). NMe-histidine ring shifts at $\delta_{C} 110.5, \delta_{C} 128.2$, and $\delta_{H} 6.76 / \delta_{C} 109.5$ revealed that the non-protonated carbon at $\delta_{C}$ 128.2 bore one of the three halogen atoms.

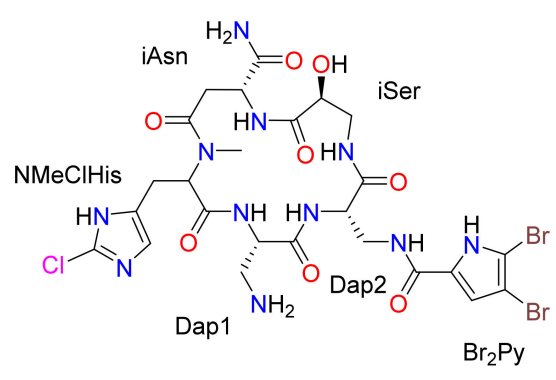

1

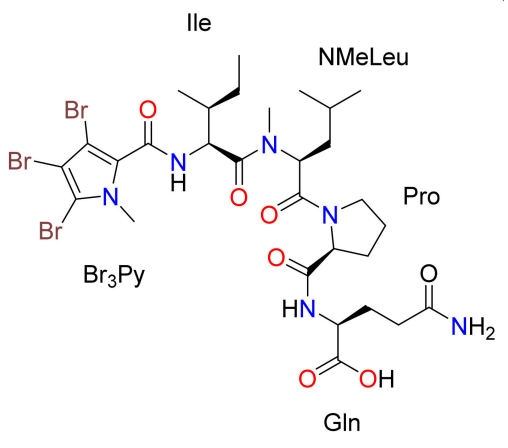

2

Figure 1. Chemical structures of the compounds $\mathbf{1}$ and $\mathbf{2}$ isolated from Ircinia sp.

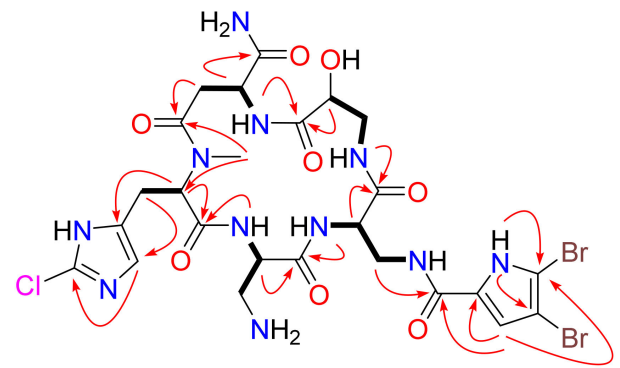

1

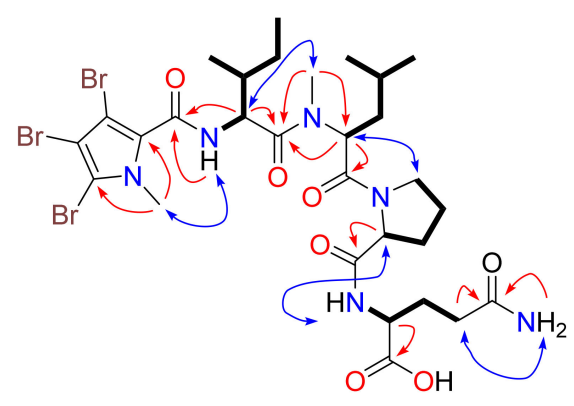

2

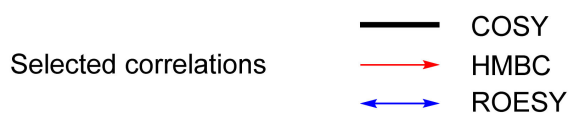

Figure 2. Selected key COSY (bold), HMBC (red), and ROESY (blue) correlations for $\mathbf{1}$ and $\mathbf{2}$. 
Table 1. NMR spectroscopy data for $\mathbf{1}\left({ }^{1} \mathrm{H}\right.$ NMR MHz, ${ }^{13} \mathrm{C}$ NMR $\left.125 \mathrm{MHz}\right)$.

\begin{tabular}{|c|c|c|c|c|c|}
\hline & Pos & $\delta_{\mathrm{C}}$, Mult $^{a}$ & $\delta_{\mathrm{H}}$, Mult $(J \text { in } \mathrm{Hz})^{a}$ & $\delta_{\mathrm{C}}, \mathrm{Mult}^{b}$ & $\delta_{\mathrm{H}}$, Mult $(J \text { in Hz})^{b}$ \\
\hline \multirow[t]{6}{*}{ Dap1 } & 1 & $169.5, \mathrm{C}$ & & $172.3, \mathrm{C}$ & \\
\hline & 2 & $50.3, \mathrm{CH}$ & 4.23 ddd $(6.2,6.2,2.8)$ & $52.2, \mathrm{CH}$ & $4.54 \mathrm{dd}(5.6,2.9)$ \\
\hline & 3 & $49.2, \mathrm{CH}_{2}$ & $2.87 \mathrm{~d}(13.9,6.2)$ & $50.5, \mathrm{CH}_{2}$ & $3.17 \mathrm{dd}(14.6,5.6)$ \\
\hline & & & $3.13 \mathrm{~d}(13.9,2.8)$ & & $3.54 \mathrm{~d}(14.2)$ \\
\hline & $\mathrm{NH}$ & & $9.11 \mathrm{~d}(6.2)$ & & $8.97 \mathrm{~d}(6.6)^{*}$ \\
\hline & $\mathrm{NH}_{2}$ & & & & \\
\hline \multirow[t]{7}{*}{$\mathrm{NMeClHis}$} & 1 & $169.0, \mathrm{CO}$ & & $170.9, \mathrm{CO}$ & \\
\hline & 2 & $65.6, \mathrm{CH}$ & $3.99 \mathrm{dd}(10.6,3.9)$ & $67.0, \mathrm{CH}$ & $4.06 \mathrm{dd}(10.1,4.5)$ \\
\hline & 3 & $24.9, \mathrm{CH}_{2}$ & $3.05 \mathrm{~m}$ & $25.9, \mathrm{CH}_{2}$ & $\begin{array}{c}3.19 \mathrm{dd}(15.2,10.1) \\
3.30 \mathrm{dd}(15.2,4.5)\end{array}$ \\
\hline & 4 & $110.5, \mathrm{C}$ & & $135.6, \mathrm{C}$ & \\
\hline & 5 & $109.5, \mathrm{CH}$ & $6.76 \mathrm{~s}$ & $120.8, \mathrm{CH}$ & $6.96 \mathrm{~s}$ \\
\hline & 6 & $128.2, \mathrm{C}$ & & $131.0, \mathrm{C}$ & \\
\hline & $\mathrm{NMe}$ & $39.6, \mathrm{CH}_{3}$ & $2.84 \mathrm{~s}$ & $40.4, \mathrm{CH}_{3}$ & $3.02 \mathrm{~s}$ \\
\hline \multirow[t]{7}{*}{$i A s n$} & 1 & $173.5, \mathrm{C}$ & & $175.8, \mathrm{C}$ & \\
\hline & 2 & $35.0, \mathrm{CH}_{2}$ & $2.80 \mathrm{dd}(16.6,2.7)$ & $36.2, \mathrm{CH}_{2}$ & $3.02 \mathrm{~m}$ \\
\hline & & & 3.09 dd $(16.6,5.8)$ & & $3.27 \mathrm{~m}$ \\
\hline & 3 & $48.4, \mathrm{CH}$ & $4.58 \mathrm{ddd}(8.0,5.8,2.7)$ & $50.3, \mathrm{CH}$ & $4.84 \mathrm{~m}$ \\
\hline & 4 & $172.2, \mathrm{CO}$ & & $173.8, \mathrm{CO}$ & \\
\hline & $\mathrm{NH}$ & & $7.13 \mathrm{~d}(8.0)$ & & $7.61 \mathrm{~d}(6.3) *$ \\
\hline & $\mathrm{NH}_{2}$ & & & & \\
\hline \multirow[t]{5}{*}{ iSer } & 1 & $171.9, \mathrm{C}$ & & 173.3, C & \\
\hline & 2 & $67.8, \mathrm{CH}$ & $4.13 \mathrm{dd}(9.0,4.2)$ & $69.5, \mathrm{CH}$ & $4.40 \mathrm{dd}(9.5,4.0)$ \\
\hline & 3 & $42.8, \mathrm{CH}_{2}$ & 2.75 ddd $(9.0,9.4,5.4)$ & $44.2, \mathrm{CH}_{2}$ & $3.00 \mathrm{~m}$ \\
\hline & & & $3.47 \mathrm{~m}$ & & $3.75 \mathrm{dd}(13.2,4.0)$ \\
\hline & $\mathrm{NH}$ & & $8.23 \mathrm{t}(5.4)$ & & $8.25 \mathrm{~s} *$ \\
\hline \multirow[t]{6}{*}{ Dap2 } & 1 & $170.5, \mathrm{C}$ & & $172.8, \mathrm{C}$ & \\
\hline & 2 & $51.5, \mathrm{CH}$ & 4.49 ddd $(9.2,9.2,6.3)$ & $53.4, \mathrm{CH}$ & $4.84 \mathrm{~m}$ \\
\hline & 3 & $40.1, \mathrm{CH}_{2}$ & $3.22 \mathrm{~m}$ & 41.6, $\mathrm{CH}_{2}$ & $3.57 \mathrm{dd}(13.8,8.6)$ \\
\hline & & & $\begin{array}{c}4.04 \operatorname{ddd}(12.9,6.3 \\
6.3)\end{array}$ & & $4.22 \mathrm{dd}(13.8,5.4)$ \\
\hline & $\mathrm{NH}-1$ & & $7.72 \mathrm{~d}(9.2)$ & & $7.98 \mathrm{~d}(9.5)$ * \\
\hline & $\mathrm{NH}-2$ & & $7.20 \mathrm{t}(6.3,6.3)$ & & $7.37 \mathrm{t}(6.0)$ * \\
\hline \multirow[t]{6}{*}{$\mathrm{Br}_{2} \mathrm{Py}$} & 1 & $158.6, \mathrm{CO}$ & & $161.4, \mathrm{CO}$ & \\
\hline & 2 & $118.0, \mathrm{C}$ & & $120.2, \mathrm{C}$ & \\
\hline & 3 & $110.4, \mathrm{CH}$ & $6.30 \mathrm{~d}(2.7)$ & $112.0, \mathrm{CH}$ & $6.15 \mathrm{~s}$ \\
\hline & 4 & $96.9, \mathrm{C}$ & & $99.4, \mathrm{C}$ & \\
\hline & 5 & $123.2, \mathrm{C}$ & & $124.2, \mathrm{C}$ & \\
\hline & $\mathrm{NH}$ & & $12.68 \mathrm{~d}(2.7)$ & & $12.03 \mathrm{~s}$ \\
\hline
\end{tabular}

${ }^{a}$ In DMSO-d $\mathrm{d}_{6} \cdot{ }^{b} \operatorname{In~} \mathrm{CD}_{3} \mathrm{OD}\left({ }^{*} \mathrm{CD}_{3} \mathrm{OH}\right)$.

To complete the structure elucidation, the two remaining doublets with a small coupling constant value of $2.7 \mathrm{~Hz}$ were assigned to an $\mathrm{sp}^{2}$ methine at $\delta_{\mathrm{H}} 6.30 / \delta_{\mathrm{C}} 110.4$ and a significant downfield $\mathrm{NH}$ signal at $\delta_{\mathrm{H}}$ 12.68. An HMBC correlation of these two protons with three non-protonated $\mathrm{sp}^{2}$ carbons $\left(\delta_{C} 96.9,118.1\right.$, and 123.2), demonstrated the existence of a trisubstituted pyrrol moiety, with two of these three positions bearing halogens. The placement of this heterocycle was established by the HMBC correlation of the methylene group of Dap2 with a carbonyl group at $\delta_{C} 158.6$. To confirm the direct connection between the pyrrol moiety and this carbonyl group, a new gHMBC experiment with $\mathrm{J}=3 \mathrm{~Hz}$ was conducted. The position of the $\mathrm{sp}^{2}$ methine in the pyrrol unit and the bond to the ring with the cyclopeptide was settled by the HMBC correlation between the methine proton at $\delta_{\mathrm{H}} 6.30$ and the carbonyl group at $\delta_{\mathrm{C}}$ 158.6. Although the chlorine and two bromine atoms were undoubtedly located on the three free positions of the heterocycle ring and the carbon shifts $\left(\delta_{C} 96.9\right.$ and 123.2) suggested that both bromine atoms were on the pyrrol moiety, this evidence was insufficient to fully confirm this proposal. Fortunately, this could be resolved by detailed study of the peptide 
structure by (+)-HRESI-TOFMS and QTOFMS (Figure 3), which showed significant cluster ions at $m / z 158.0487 / 160.0460$ in a 3:1 ratio corresponding to the iAsn moiety. These $m / z$ values, the mass error observed, and the isotopic distribution clearly confirmed the presence of a chlorine atom on the NMeHis amino acid (Figure S30).

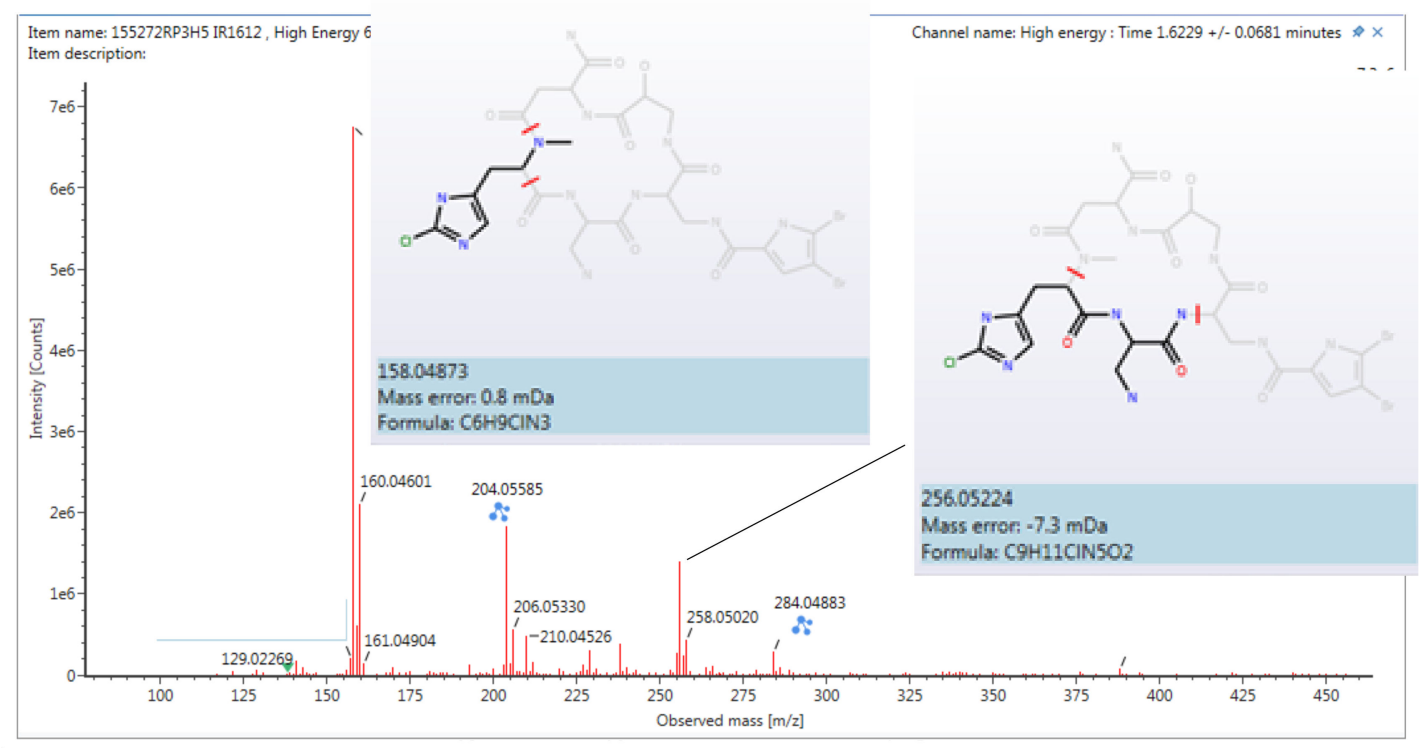

Figure 3. Fragment found for 1 by QTOF.

The absolute stereochemistry of compound 1 was established on the basis of Marfey's analysis with the 1-fluoro-2,4-di-nitrophenyl-5-L-alanine amide (L-FDAA) [25]. Compound 1 was hydrolyzed in strong acid conditions and derivatization of the free amino acids with L-FDAA allowed an exhaustive analysis by HPLC-MS. A comparison of the retention times of the derivatized amino acids present in $\mathbf{1}$ and the suitably derivatized pure amino acid standards unambiguously demonstrated the absolute configuration as L-Dap, L-iSer, and D-Asn. The absolute configuration of NMeClHis could not be determined due to the absence of the standard amino acid.

Compound 2 was isolated as an amorphous white solid. Its (+)-LRESI showed an $m / z=825[\mathrm{M}+\mathrm{H}]^{+}$ with a characteristic cluster corresponding to the presence of three bromine atoms. The molecular formula $\mathrm{C}_{29} \mathrm{H}_{43}{ }^{79} \mathrm{Br}_{3} \mathrm{~N}_{6} \mathrm{O}_{7}$ was established by (+)-HRESI-TOFMS analysis of the $[\mathrm{M}+\mathrm{H}]^{+}$at $\mathrm{m} / \mathrm{z}$ 825.0806 (calcd. 825. 0816). The peptide nature of 2 was evident from its ${ }^{1} \mathrm{H}$ and ${ }^{13} \mathrm{C}$ NMR spectra (Table 2). ${ }^{1} \mathrm{H}$ NMR in DMSO showed the characteristic $\alpha$-proton resonances of four $\alpha$-amino acids in the range $\delta_{\mathrm{H}} 5.35$ to $4.10 \mathrm{ppm}$, five interchangeable protons at $\delta_{\mathrm{H}} 12.53,8.56,8.08,7.19$, and $6.77 \mathrm{ppm}$, and two NMe signals at $\delta_{\mathrm{H}} 3.61$ and $3.04 \mathrm{ppm} .{ }^{13} \mathrm{C}$ NMR data displayed six carbonyl signals between $\delta_{\mathrm{C}}$ 173.5 and $159.1 \mathrm{ppm}$, four adjacent methine carbons in the range $\delta_{C} 59.1-51.5 \mathrm{ppm}$, and two NMe signals at $\delta_{C} 35.7$ and $30.5 \mathrm{ppm}$. Extensive 2D NMR analysis, including COSY, TOCSY, HSQC, and HMBC was used to determine the identity of the four amino acids and to assign the NMR signals. As a result of these studies, the amino acids were found to be one Ile, one NMe-Leu, one Pro, and one Asn unit. A long-range correlation between protons at $\delta_{\mathrm{H}} 7.19 / 6.77$ and 2.15/2.11 ppm with the carbonyl group at $\delta_{\mathrm{C}} 173.5 \mathrm{ppm}$ and the observation of ROESY cross-peaks between protons at $\delta_{\mathrm{H}} 7.19 / 6.77 \mathrm{ppm}$ and the $\mathrm{CH}_{2}$ of position 4 at $\delta_{\mathrm{H}}$ 2.15/2.11 ppm established the presence of a Gln. A N-methyl-2,3,4-bromopyrrol unit was inferred by the presence of four aromatic non-protonated carbons at $\delta_{C} 128.5,107.9,100.7$ and 93.4 ppm with chemical shifts similar to those described for bromopseudoceratines [23].

The sequencing for compound 2 was carried out using a combination of HMBC and ROESY data. Long-range correlations from $\alpha$-protons, $\mathrm{NH}$, and $\mathrm{NMe}$ to carbonyl carbons of adjacent amino acids plus ROESY correlations between $\alpha$-protons, $\mathrm{NH}$, and NMe protons of adjacent amino acids (see Figure 2) allowed us to establish the sequence as $\mathrm{Br}_{3} \mathrm{Py}-\mathrm{Ile}-\mathrm{NMeLeu-Pro-GIn}$. 
Table 2. NMR spectroscopy data for $2\left({ }^{1} \mathrm{H}\right.$ NMR $500 \mathrm{MHz},{ }^{13} \mathrm{C}$ NMR $\left.125 \mathrm{MHz}\right)$.

\begin{tabular}{|c|c|c|c|c|c|}
\hline & Pos & $\delta_{\mathrm{H}}$, Mult $(J \text { in } \mathrm{Hz})^{a}$ & $\delta_{C}$, Mult $^{\text {a }}$ & $\delta_{\mathrm{H}}$, Mult $(J \text { in } \mathrm{Hz})^{b}$ & $\delta_{C}$, Mult ${ }^{b}$ \\
\hline \multirow[t]{6}{*}{$\mathrm{Br}_{3} \mathrm{Py}$} & 1 & - & $161.8, \mathrm{CO}$ & - & $159.1, \mathrm{CO}$ \\
\hline & 2 & - & $128.6, \mathrm{C}$ & - & $128.5, \mathrm{C}$ \\
\hline & 3 & - & 102.7, C & - & 100.7, C \\
\hline & 4 & - & 101.3, C & - & $93.4, \mathrm{C}$ \\
\hline & 5 & - & $110.8, \mathrm{C}$ & - & $107.9, \mathrm{C}$ \\
\hline & $\mathrm{NMe}$ & $3.76, \mathrm{~s}$ & $36.7, \mathrm{CH}_{3}$ & $3.61, \mathrm{~s}$ & $35.7, \mathrm{CH}_{3}$ \\
\hline \multirow[t]{7}{*}{ Ile } & 1 & - & $174.3, \mathrm{CO}$ & - & $171.4, \mathrm{CO}$ \\
\hline & 2 & $4.84, \mathrm{~m}$ & $55.7, \mathrm{CH}$ & $4.65, \mathrm{dd}, 8.35,8.5$ & $53.7, \mathrm{CH}$ \\
\hline & 3 & $1.96, \mathrm{~m}$ & $38.0, \mathrm{CH}$ & $1.87, \mathrm{~m}$ & $35.8, \mathrm{CH}$ \\
\hline & 4 & $1.73, \mathrm{~m}, 1.22, \mathrm{~m}$ & $25.9, \mathrm{CH}_{2}$ & $1.57, \mathrm{~m} ; 1.21, \mathrm{~m}$ & $24.2, \mathrm{CH}_{2}$ \\
\hline & 5 & $0.95, \mathrm{t}, 7.4$ & $11.2, \mathrm{CH}_{3}$ & $0.83, \mathrm{t}, 7.4$ & $10.7, \mathrm{CH}_{3}$ \\
\hline & 6 & $0.99, \mathrm{~d}, 6.8$ & $15.7, \mathrm{CH}_{3}$ & $0.85, \mathrm{~d}, 6.9$ & $15.1, \mathrm{CH}_{3}$ \\
\hline & $\mathrm{NH}$ & $8.24, d, 8.1$ & - & $8.56, d, 8.2$ & - \\
\hline \multirow[t]{7}{*}{ NMeLeu } & 1 & - & $171.8, \mathrm{CO}$ & - & $168.8, \mathrm{CO}$ \\
\hline & 2 & $5.51, \mathrm{dd}, 10.3,4.7$ & $54.3, \mathrm{CH}$ & $5.35, \mathrm{dd}, 10.1,4.3$ & $51.7, \mathrm{CH}$ \\
\hline & 3 & $1.77, \mathrm{~m} ; 1.61, \mathrm{~m}$ & 38.0, $\mathrm{CH}_{2}$ & $1.59, \mathrm{~m} ; 1.42, \mathrm{~m}$ & $36.7, \mathrm{CH}_{2}$ \\
\hline & 4 & $1.56, \mathrm{~m}$ & $25.7, \mathrm{CH}$ & $1.43, \mathrm{~m}$ & $23.9, \mathrm{CH}$ \\
\hline & 5 & $0.97, d, 6.2$ & 23.6, $\mathrm{CH}_{3}$ & $0.87, d, 6.2$ & $23.1, \mathrm{CH}_{3}$ \\
\hline & 6 & $0.93, d, 6.1$ & $22.3, \mathrm{CH}_{3}$ & $0.83, d, 6.2$ & $21.8, \mathrm{CH}_{3}$ \\
\hline & $\mathrm{NMe}$ & $3.21, \mathrm{~s}$ & $31.8, \mathrm{CH}_{3}$ & $3.04, \mathrm{~s}$ & $30.5, \mathrm{CH}_{3}$ \\
\hline \multirow[t]{5}{*}{ Pro } & 1 & - & $174.5, \mathrm{CO}$ & - & $171.4, \mathrm{CO}$ \\
\hline & 2 & $4.41, \mathrm{~m}$ & $61.6, \mathrm{CH}$ & $4.31, \mathrm{dd}, 8.3,4.1$ & $59.1, \mathrm{CH}$ \\
\hline & 3 & $2.23, \mathrm{~m} ; 2.00, \mathrm{~m}$ & $30.5, \mathrm{CH}_{2}$ & $2.02, \mathrm{~m} ; 1.80, \mathrm{~m}$ & $28.9, \mathrm{CH}_{2}$ \\
\hline & 4 & $2.08, \mathrm{~m} ; 1.92, \mathrm{~m}$ & $26.0, \mathrm{CH}_{2}$ & $1.90, \mathrm{~m} ; 1.77, \mathrm{~m}$ & $24.4, \mathrm{CH}_{2}$ \\
\hline & 5 & $3.75, \mathrm{~m} ; 3.69, \mathrm{~m}$ & $48.8, \mathrm{CH}_{2}$ & $3.53, \mathrm{~m} ; 3.50 ; \mathrm{m}$ & $46.7, \mathrm{CH}_{2}$ \\
\hline \multirow[t]{6}{*}{ Gln } & 1 & - & $174.7, \mathrm{CO}_{2} \mathrm{H}$ & 12.53, brs & $173.3, \mathrm{CO}_{2} \mathrm{H}$ \\
\hline & 2 & $4.41, \mathrm{~m}$ & $52.8, \mathrm{CH}$ & $4.10, \mathrm{ddd}, 8.6,8.5,5.2$ & $51.5, \mathrm{CH}$ \\
\hline & 3 & $2.27, \mathrm{~m} ; 1.92, \mathrm{~m}$ & $30.5, \mathrm{CH}_{2}$ & $1.93, \mathrm{~m} ; 1.74, \mathrm{~m}$ & 27.0, $\mathrm{CH}_{2}$ \\
\hline & 4 & $2.41, \mathrm{~m} ; 2.32, \mathrm{~m}$ & $32.6, \mathrm{CH}_{2}$ & $2.15, \mathrm{~m} ; 2.11, \mathrm{~m}$ & $31.3, \mathrm{CH}_{2}$ \\
\hline & 5 & - & $\begin{array}{c}177.9 \\
\mathrm{CONH}_{2}\end{array}$ & $7.19, \mathrm{~s} ; 6.77, \mathrm{~s}$ & $\begin{array}{c}173.5 \\
\mathrm{CONH}_{2}\end{array}$ \\
\hline & $\mathrm{NH}$ & - & - & 8.08, brs & - \\
\hline
\end{tabular}

${ }^{a}$ In $\mathrm{CD}_{3} \mathrm{OD} .{ }^{b}$ In DMSO- $d_{6}$.

The absolute configurations of the amino acids were determined by comparing the hydrolysis products of $2\left(6 \mathrm{~N} \mathrm{HCl}, 110{ }^{\circ} \mathrm{C}, 18 \mathrm{~h}\right)$ after derivatization with Marfey's reagent (N-(3-fluoro-4,6-dinitrophenyl)-L-alaninamide, L-FDAA), with appropriate amino acid standards using HPLC-MS chromatography. As a result, all the amino acids were determined to be $L$.

\section{Materials and Methods}

\subsection{General Experimental Procedures}

Optical rotations were determined using a Jasco P-1020 polarimeter. UV spectra were performed using an Agilent 8453 UV-vis spectrometer. IR spectra were obtained with a Perkin-Elmer Spectrum 100 FT-IR spectrometer with ATR sampling. NMR spectra were recorded on a Varian “Unity 500 " spectrometer at $500 / 125 \mathrm{MHz}\left({ }^{1} \mathrm{H} /{ }^{13} \mathrm{C}\right)$. Chemical shifts were reported in ppm using residual $\mathrm{CD}_{3} \mathrm{OH}(\delta 3.31 \mathrm{ppm}$ for ${ }^{1} \mathrm{H}$ and $49.0 \mathrm{ppm}$ for $\left.{ }^{13} \mathrm{C}\right)$ and DMSO- $\mathrm{d}_{6}\left(\delta 2.50 \mathrm{ppm}\right.$ for ${ }^{1} \mathrm{H}$ and $39.5 \mathrm{ppm}$ for $\left.{ }^{13} \mathrm{C}\right)$ as an internal reference. HRESI-TOFMS was performed on an Agilent 6230 TOF LC/MS chromatograph spectrometer. (+)-ESIMS were recorded using an Agilent 1100 Series LC/MSD spectrometer. HRESI-TOFMS was performed on an Agilent 6230 TOF LC/MS chromatograph spectrometer. ESI(+) and MSe were performed on an Waters UHPLC-QTOF Acquity I-Class + Xevo G2-XS. 


\subsection{Biological Material}

The sponge Ircinia sp. (158 g) was collected by hand using a diving rebreather system in the Thousand Islands (Indonesia). The sponge was immediately frozen and kept under these conditions until extraction. The specimen was identified by María Jesús Uriz at CEAB, Blanes, Spain. A voucher specimen (ORMA155272) was deposited at PharmaMar facilities (Madrid, Spain).

\subsection{Extraction and Isolation}

The sponge Ircinia sp. (158 g) was triturated and exhaustively extracted with MeOH:DCM (1:1, $3 \times 500 \mathrm{~mL}$ ). The combined extracts were concentrated to yield a crude mass of $7.9 \mathrm{~g}$. The crude product was subjected to VLC on a Lichroprep RP- 18 with a stepped gradient from $\mathrm{H}_{2} \mathrm{O}$ to $\mathrm{MeOH}$ to $\mathrm{CH}_{2} \mathrm{Cl}_{2}$. The fractions eluting with $\mathrm{H}_{2} \mathrm{O}: \mathrm{MeOH}(3: 1,606 \mathrm{mg})$ and $\mathrm{H}_{2} \mathrm{O}: \mathrm{MeOH}(1: 1,89.6 \mathrm{mg})$ were subjected to semipreparative HPLC (Symmetry Prep $\mathrm{C}_{18} 5 \mu \mathrm{m}, 10 \times 150 \mathrm{~mm} ; 3 \mathrm{~min}$ isocratic $\mathrm{H}_{2} \mathrm{O}+$ 0.04\% TFA: $\mathrm{CH}_{3} \mathrm{CN}+0.04 \%$ TFA 95:5 and then gradient from $5 \%$ to $68 \% \mathrm{CH}_{3} \mathrm{CN}+0.04 \%$ TFA in $25 \mathrm{~min}$, flow $3 \mathrm{~mL} / \mathrm{min}$, UV detection) to obtain $4.3 \mathrm{mg}$ of compound 1. The fraction eluting with $\mathrm{H}_{2} \mathrm{O}: \mathrm{MeOH}$ $\left(1: 3,43.9 \mathrm{mg}\right.$ ) was subjected to semipreparative HPLC (Symmetry Prep $C_{18} 5 \mu \mathrm{m}, 10 \times 150 \mathrm{~mm} ; 3 \mathrm{~min}$. isocratic $\mathrm{H}_{2} \mathrm{O}+0.04 \%$ TFA: $\mathrm{CH}_{3} \mathrm{CN}+0.04 \%$ TFA 90:10 and then gradient from $10 \%$ to $75 \% \mathrm{CH}_{3} \mathrm{CN}+$ $0.04 \%$ TFA in $25 \mathrm{~min}$, flow $3 \mathrm{~mL} / \mathrm{min}$, UV detection) to obtain $3.0 \mathrm{mg}$ of compound 2.

Haloirciniamide A (1): amorphous white solid; $[\alpha]^{25} \mathrm{D}-62.7^{\circ}$ (c $\left.0.1, \mathrm{MeOH}\right)$; IR vmax 3314, 2920, 2850, 1644, 1523, 1416, 1311, 1239, 1199, $1041 \mathrm{~cm}^{-1}$; UV (MeOH) $\lambda_{\max } 198,268 \mathrm{~nm} .{ }^{1} \mathrm{H}$ NMR $(500 \mathrm{MHz})$ and ${ }^{13} \mathrm{C}$ NMR $(125 \mathrm{MHz})$ see Table $1 ;(+)$-HREI-TOFMS $\mathrm{m} / \mathrm{z} 830.0400[\mathrm{M}+\mathrm{Na}]^{+}$(calcd for $\mathrm{C}_{25} \mathrm{H}_{32}{ }^{79} \mathrm{Br}_{2} \mathrm{~N}_{11} \mathrm{O}_{8} \mathrm{Na} m / z$ 830.0383).

Seribunamide A (2): amorphous white solid; $[\alpha]^{25} \mathrm{D}-38.4^{\circ}$ (c $\left.0.2, \mathrm{MeOH}\right)$; IR vmax 3352, 2932, 2850, 1658, 1515, 1320, 1236, and $1035 \mathrm{~cm}^{-1}$; UV (MeOH) $\lambda_{\max }$ 197, $266 \mathrm{~nm} .{ }^{1} \mathrm{H} \mathrm{NMR}(500 \mathrm{MHz})$ and ${ }^{13} \mathrm{C}$ NMR (125 MHz) see Table 2; (+)-HREI-TOFMS $m / z$ 825.0806 [M + H] $]^{+}$(calcd for $\mathrm{C}_{29} \mathrm{H}_{44}{ }^{79} \mathrm{Br}_{3} \mathrm{~N}_{6} \mathrm{O}_{7}$ $\mathrm{m} / \mathrm{z}$ 825.0816).

\subsection{Absolute Configuration}

Absolute Configuration of 1. First, $0.5 \mathrm{mg}$ of haloirciniamide A was hydrolyzed in $0.5 \mathrm{~mL}$ of $6 \mathrm{~N}$ $\mathrm{HCl}$ at $110{ }^{\circ} \mathrm{C}$ for $15 \mathrm{~h}$. The excess aqueous $\mathrm{HCl}$ was removed under a $\mathrm{N}_{2}$ stream, and a solution of $700 \mu \mathrm{g}$ of L-FDAA ( $\mathrm{N}$-(3-fluoro-4,6-dinitrophenyl)-L-alanine-amide) in acetone $(160 \mu \mathrm{L}), \mathrm{H}_{2} \mathrm{O}(100 \mu \mathrm{L})$, and $\mathrm{NaHCO}_{3} 1 \mathrm{~N}(50 \mu \mathrm{L})$ was added to the dry hydrolysate. The resulting mixture was heated at $40{ }^{\circ} \mathrm{C}$ for $1 \mathrm{~h}$, before being cooled to $23^{\circ} \mathrm{C}$, quenched by addition of $2 \mathrm{~N} \mathrm{HCl}(20 \mu \mathrm{L})$, dried, and dissolved in $\mathrm{H}_{2} \mathrm{O}(800 \mu \mathrm{L})$. The resultant aqueous solution was subjected to reversed-phase LC/MS (column: Waters Symmetry $4.6 \times 150 \mathrm{~mm}, 3.5 \mu \mathrm{m}$, flow rate $0.8 \mathrm{~mL} / \mathrm{min}$ ) in three different gradients.

Gradient 1 for iSer (mobile phase $\mathrm{CH}_{3} \mathrm{CN}+0.04 \%$ formic acid $/ \mathrm{H}_{2} \mathrm{O}+0.04 \%$ formic acid, using a linear gradient from $5 \%$ to $20 \% \mathrm{CH}_{3} \mathrm{CN}$ in $10 \mathrm{~min}$ and then from $20 \%$ to $35 \% \mathrm{CH}_{3} \mathrm{CN}$ in $25 \mathrm{~min}$ ): the retention time was $23.9 \mathrm{~min}$ for L-iSer.

Gradient 2 for Asp (mobile phase $\mathrm{CH}_{3} \mathrm{CN}+0.04 \%$ formic acid $/ \mathrm{H}_{2} \mathrm{O}+0.04 \%$ formic acid, using a linear gradient from $5 \%$ to $30 \% \mathrm{CH}_{3} \mathrm{CN}$ in $10 \mathrm{~min}$ and then from $30 \%$ to $50 \% \mathrm{CH}_{3} \mathrm{CN}$ in $30 \mathrm{~min}$ ): the retention time was $17.0 \mathrm{~min}$ for $\mathrm{D}$-Asp.

Gradient 3 for Dap: mobile phase $\mathrm{CH}_{3} \mathrm{CN}+0.04 \%$ formic acid $/ \mathrm{H}_{2} \mathrm{O}+0.04 \%$ formic acid, using a linear gradient from $5 \%$ to $10 \% \mathrm{CH}_{3} \mathrm{CN}$ in $5 \mathrm{~min}$ and then from $10 \%$ to $35 \% \mathrm{CH}_{3} \mathrm{CN}$ in $25 \mathrm{~min}$ ): the retention times was 15.5 min for L-Dap.

Retention times for the derivatized amino acids standards were as follows: gradient 1 (23.2 min for D-iSer and $23.8 \mathrm{~min}$ for the L-iSer); gradient 2 (16.2 $\mathrm{min}$ for L-Asp and $17.0 \mathrm{~min}$ for $\mathrm{D}-\mathrm{Asp}$ ), and gradient 3 (15.5 min for L-Dap and 16.6 min for the D-Dap).

Absolute Configuration of 2. First, $0.3 \mathrm{mg}$ of seribunamide A was hydrolyzed in $0.4 \mathrm{~mL}$ of $6 \mathrm{~N} \mathrm{HCl}, 110^{\circ} \mathrm{C}$ for $15 \mathrm{~h}$. The excess aqueous $\mathrm{HCl}$ was removed under a $\mathrm{N}_{2}$ stream, and a solution of $400 \mu \mathrm{g}$ of L-FDAA (N-(3-fluoro-4,6-dinitrophenyl)-L-alanine-amide) in acetone $(160 \mu \mathrm{L}), \mathrm{H}_{2} \mathrm{O}(100 \mu \mathrm{L})$, 
and $\mathrm{NaHCO}_{3} 1 \mathrm{~N}(50 \mu \mathrm{L})$ was added. The vial was heated at $40{ }^{\circ} \mathrm{C}$ for $1 \mathrm{~h}$, and the contents were neutralized with $2 \mathrm{~N} \mathrm{HCl}(20 \mu \mathrm{L})$ after cooling to room temperature. The resulting solution was dried in vacuum and reconstituted in $\mathrm{H}_{2} \mathrm{O}(600 \mu \mathrm{L})$ before being analyzed by HPLC-MS using two different methods.

Ile was analyzed using Lux Cellulose- $4,5 \mu \mathrm{m}$, flow $1 \mathrm{~mL} / \mathrm{min}, \mathrm{H}_{2} \mathrm{O} / \mathrm{AcN}+0.04 \%$ TFA isocratic $65: 35 \mathrm{in} 60 \mathrm{~min}$. The retention time of the L-FDAA amino acid in the hydrolysate of 2 was established as L-Ile $36.1 \mathrm{~min}$. Retention times for the derivatized amino acids standards were as follows: L-allo-Ile $31.7 \mathrm{~min}$, L-Ile $36.1 \mathrm{~min}$, D-allo-Ile $38.1 \mathrm{~min}$, and D-Ile $51.4 \mathrm{~min}$.

Pro, NMeLeu, and Glu were analyzed using Symmetry $4.6 \times 150 \mathrm{~mm}, 3.5 \mu \mathrm{m}$, flow $0.8 \mathrm{~mL} / \mathrm{min}$, $\mathrm{H}_{2} \mathrm{O}+0.04 \%$ TFA $/ \mathrm{CH}_{3} \mathrm{CN}+0.04 \%$ TFA from $20 \%$ to $50 \%$ in $30 \mathrm{~min}$. The retention time of the L-FDAA amino acids in the hydrolysate of 2 were established as L-Glu $14.0 \mathrm{~min}$, L-Pro $16.8 \mathrm{~min}$, and NMe-L-Leu $28.5 \mathrm{~min}$. Retention times for the derivatized amino acids standards were as follows: L-Glu $14.1 \mathrm{~min}$, D-Glu $15.2 \mathrm{~min}$, L-Pro $16.8 \mathrm{~min}$, D-Pro $14.01 \mathrm{~min}$, NMe-L-Leu $28.5 \mathrm{~min}$, and NMe-D-Leu $30.1 \mathrm{~min}$.

\subsection{Biological Activity}

The cytotoxic activity of $\mathbf{1}$ and $\mathbf{2}$ was tested against four human tumor cell lines, lung (A-549), colon (HT-29), breast (MDA-MB-231), and pancreas PSN-1, and both compounds displayed a $\mathrm{GI}_{50}>$ $1.2 \times 10^{-5} \mathrm{M}$ in all cell lines. Since these compounds did not show cytotoxicity, we further evaluated an anticancer response through other targets. Thus, compound $\mathbf{1}$ was further tested for the capacity to inhibit the enzyme topoisomerase I, but it showed no inhibition of the enzyme at $1.0 \times 10^{-5} \mathrm{M}$, and therefore, it was not considered active in inhibiting this enzyme. Likewise, compounds 1 and 2 were unable to impair the interaction between the programmed cell death protein PD-1 and its natural ligand PDL1 as demonstrated by their lack of effect in a cell-based assay whose final readout was dependent on the interaction between the two proteins (Table 3).

Table 3. \% PD-1 and TOPO-I inhibition for compounds 1 and 2. PD-1: programmed cell death protein.

\begin{tabular}{ccc}
\hline Compound & Target & \%Inhibition at $\mathbf{1} \times \mathbf{1 0}^{-\mathbf{5}} \mathbf{M}$ \\
\hline $\mathbf{1}$ & Top-I & 3 \\
$\mathbf{1}$ & PD-1 & 0.3 \\
$\mathbf{2}$ & PD-1 & -3.5 \\
\hline
\end{tabular}

\section{Conclusions}

In summary, two new peptides bearing unprecedented halogenated moieties, haloirciniamide A (1) and seribunamide A (2), were isolated from a marine sponge belonging to the Irnicia genus, which was selected for further studies. The sample was collected around the Thousand Islands (Indonesia) by the Pharmamar expedition team in collaboration with the Research Center for Oceanography, Indonesian Institute of Sciences (RCO-LIPI). The planar structures of the novel compounds were determined by a combination of extensive NMR and HPLC-MS experiments. The absolute configuration was achieved by Marfey's analysis after acid hydrolysis. Cytotoxic activity in the four cancer cell lines tested was not observed for $\mathbf{1}$ and $\mathbf{2}$, as in the case of gunungamide A and cyclocinamide B. In addition, an anticancer immune response was also evaluated, and neither compound was able to impair PD1-PDL1 interaction. Moreover, compound $\mathbf{1}$ failed to inhibit the enzyme topoisomerase I. Unfortunately, the amount of the compounds isolated was not enough for further assays. This work is the first example of the isolation and structural elucidation of novel compounds with unique structural features from an Ircinia sponge, which highlights this gender and its microbiota as a distinctive source of novel structures.

Supplementary Materials: The following are available online at http://www.mdpi.com/1660-3397/18/8/396/s1, Figure S1: Picture of the fresh sponge; Figures S2-S16: NMR spectra of compound 1. Figures S17-S29: NMR spectra of compound 2. Figures S30: QTOFMS spectrum of compound 1 and fragments found. Figures S31-S38: Analysis by Marfey's method. 
Author Contributions: Sample collection: T.A.H., A.B. and S.B.; Conceptualization and supervision: C.C. and M.Y.P.; Methodology and writing: R.F.; Investigation: A.B.; Original draft preparation and writing: M.P.; Review and editing: C.C., M.P. and M.Y.P. All the authors read, reviewed, and agreed with the structure and content of the manuscript. All authors have read and agreed to the published version of the manuscript.

Funding: The present research was financed in part by Grants from Ministerio de Ciencia, Innovación y Universidades of Spain (AGL2015-63740-C2-2-R and RTC-2016 4611-1, Inmunotop project), cofunded by the FEDER Programme from the European Union.

Acknowledgments: We gratefully acknowledge the help of our PharmaMar colleagues C. Crespo for her excellent technical assistance, E. Millán for performing the ESI(+) and MS experiments, J. M. Dominguez for the biological assays and S. Munt for revision of the manuscript.

Conflicts of Interest: The authors declare no conflict of interest.

\section{References}

1. Hanif, N.; Murni, A.; Tanaka, C.; Tanaka, J. Marine Natural Products from Indonesian Waters. Mar. Drugs 2019, 17, 364. [CrossRef] [PubMed]

2. Mehbub, M.F.; Lei, J.; Franco, C.; Zhang, W. Marine Sponge Derived Natural Products between 2001 and 2010: Trends and Opportunities for Discovery of Bioactives. Mar. Drugs 2014, 12, 4539-4577. [CrossRef] [PubMed]

3. Kawakami, A.; Miyamoto, T.; Higuchi, R.; Uchiumi, T.; Kuwano, M.; Van Soet, R.W.M. Structure of a novel multidrug resistance modulator, irciniasulfonic acid, isolated from a marine sponge Ircinia sp. Tetrahedron Lett. 2001, 42, 3335-3337. [CrossRef]

4. Sica, D.; Piccialli, V.; Pronzato, R. Sterols from the sponges Ircinia pipetta and Dysidea avara identification of cholestatrienol. Comp. Biochem. Physiol. 1987, 88, 293-296.

5. Venkateswarlu, Y.; Reddy, M.V.R.; Rao, M.N. A new epoxy sterol from the sponge Ircinia fasciculata. J. Nat. Prod. 1996, 59, 876-877. [CrossRef]

6. Issa, H.H.; Tanaka, J.; Higa, T. New cytotoxic furanosesterterpenes from an Okinawan marine sponge Ircinia sp. J. Nat. Prod. 2003, 66, 252-254. [CrossRef]

7. Lai, Y.Y.; Lu, M.C.; Wang, L.H.; Chen, J.J.; Fang, L.S.; Wu, Y.C.; Sung, P.J. New scalarane sesterterpenoids from the Formosan sponge Ircinia felix. Mar. Drugs 2015, 13, 4296-4309. [CrossRef]

8. Rashid, M.A.; Gustafson, K.R.; Boyd, M.R. New chondropsin macrolide lactams from marine sponges in the genus Ircinia. Tetrahedron Lett. 2001, 42, 1623-1626. [CrossRef]

9. Chevallier, C.; Bugni, T.S.; Feng, X.; Harper, M.K.; Orendt, A.M.; Ireland, C.M. Tedanolide C: A potent new 18-membered-ring cytotoxic macrolide isolated from the Papua New Guinea marine sponge Ircinia sp. J. Org. Chem. 2006, 71, 2510-2513. [CrossRef]

10. Feng, Y.; Caroll, A.R.; Pass, D.M.; Archbold, J.K.; Avery, V.M.; Quin, R.J. Polydiscamides B-D from a marine sponge Ircinia sp. as potent human sensory neuron-specific $\mathrm{G}$ protein coupled receptor agonists. J. Nat. Prod. 2008, 71, 8-11. [CrossRef]

11. Mohamed, A.M.; Rao, V.; Hamann, M.T.; Kelly, M.; Hill, R.T. Monitoring Bacterial Diversity of the Marine Sponge Ircinia strobilina upon Transfer into Aquaculture. Appl. Environ. Microbiol. 2008, 74, 4133-4143. [CrossRef]

12. Mau, C.; Nakao, Y.; Yoshida, W.Y.; Scheuer, P.J.; Kelly-Borges, M. Waiakeamide, a Cyclic Hexapeptide from the Sponge Ircinia dendroides. J. Org. Chem. 1996, 61, 6302-6304. [CrossRef] [PubMed]

13. Murakami, Y.; Takei, M.; Shindo, K.; Kitazume, C.; Tanaka, J.; Higa, T.; Fukamachi, H. Cyclotheonamide E4 and E5, New Potent Tryptase Inhibitors from an Ircinia Species of Sponge. J. Nat. Prod. 2002, 65, $259-261$. [CrossRef]

14. Hooper, G.J.; Orjala, J.; Schatzman, R.C.; Gerwick, W.H. Carmabins A and B, New Lipopeptides from the Caribbean Cyanobacterium Lyngbya majuscula. J. Nat. Prod. 1998, 614, 529-533. [CrossRef] [PubMed]

15. Ebada, S.S.; Wray, V.; De Voogd, N.J.; Deng, Z.; Lin, W.; Proksch, P. Two New Jaspamide Derivatives from the Marine Sponge Jaspis splendens. Mar. Drugs 2009, 7, 435-444. [CrossRef] [PubMed]

16. Fu, X.; Do, T.; Schmitz, F.J.; Andrusevich, V.; Engel, M.H. New Cyclic Peptides from the Ascidian Lissoclinum patella. J. Nat. Prod. 1998, 61, 1547-1551. [CrossRef] [PubMed]

17. McIntosh, M.; Cruz, L.J.; Hunkapiller, M.W.; Gray, W.R.; Olivera, B.M. Isolation and structure of a peptide toxin from the marine snail Conus magus. Arch. Biochem. Biophys. 1982, 218, 329-334. [CrossRef] 
18. Pettit, G.R.; Kamano, Y.; Herald, C.L.; Tuinman, A.A.; Boettner, F.E.; Kizu, H.; Schmidt, J.M.; Baczynskyj, L.; Tomer, K.B.; Bontems, R.J. The isolation and structure of a remarkable marine animal antineoplastic constituent: Dolastatin 10. J. Am. Chem. Soc. 1987, 109, 6883-6885. [CrossRef]

19. Laird, D.W.; LaBarbera, D.V.; Feng, X.D.; Bugni, T.S.; Harper, M.K.; Ireland, C.M. Halogenanted Cyclic Peptides Isolated from the Sponge Corticium sp. J. Nat. Prod. 2007, 70, 741-746. [CrossRef]

20. Tarazona, G.; Fernández, R.; Cruz, P.G.; Pérez, M.; Rodríguez, J.; Jiménez, C.; Cuevas, C. Combining JBCA and Marfey's methodology to determine the absolute configuration of threonines: The case of gunungamide A, a new cyclic depsideptide containing chloropyrrole from the sponge Discodermia sp. Org. Chem. Front. 2019, 6, 15-21. [CrossRef]

21. Yasuda, T.; Araki, A.; Kubota, T.; Ito, J.; Mikami, Y.; Fromont, J.; Kobayashi, J. Bromopyrrole Alkaloids from Marine Sponges of the Genus Agelas. J. Nat. Prod. 2009, 72, 488-491. [CrossRef] [PubMed]

22. Kobayashi, H.; Kitamura, K.; Nagai, K.; Nakao, Y.; Fusetani, N.; van Soest, R.W.M.; Matsunaga, S. Carteramine A, an inhibitor of neutrophil chemotaxis, from the marine sponge Stylissa carteri. Tetrahedron Lett. 2007, 48, 2127-2129. [CrossRef]

23. Emrich, R.; Weyland, H.; Weber, K. 2,3,4-Tribromopyrrole from the marine Polychaete Polyphysia crassa. J. Nat. Prod. 1990, 53, 703-705. [CrossRef]

24. Tebben, J.; Motti, C.; Tapiolas, D.; Thomas-Hall, P.; Harder, T. A Coralline Algal-Associated Bacterium, Pseudoalteromonas Strain J010, Yields Five New Korormicins and a Bromopyrrole. Mar. Drugs 2014, 12, 2802-2815. [CrossRef]

25. Marfey, P. Determination of D-amino acids. II. Use of a bifunctional reagent, 1,5-difluoro-2,4-dinitro-benzene. Carlsberg Res. Commun. 1984, 49, 591-596. [CrossRef]

(C) 2020 by the authors. Licensee MDPI, Basel, Switzerland. This article is an open access article distributed under the terms and conditions of the Creative Commons Attribution (CC BY) license (http://creativecommons.org/licenses/by/4.0/). 